\title{
SPATIAL MODELING OF ENVIRONMENTAL-BASED RISK FACTORS OF TUBERCULOSIS IN BALI PROVINCE: AN ECOLOGICAL STUDY
}

\author{
Pemodelan Spasial Faktor Risiko berbasis Lingkungan Kejadian Tuberkulosis di Provinsi Bali : Studi \\ Ekologi
}

\begin{abstract}
Firman Firdauz Saputra ${ }^{1}$, Chatarina Umbul Wahjuni ${ }^{2}$, Muhammad Atoillah Isfandiari ${ }^{3}$
${ }^{1}$ Epidemiology Master's Program Faculty of Public Health,Universitas Airlangga, FirmanFirdauz@ gmail.com ${ }^{2}$ Departement of Epidemiology, Faculty of Public Health,Universitas Airlangga,chatarina.uw@fkm.unair.ac.id ${ }^{3}$ Departement of Epidemiology, Faculty of Public Health, Universitas Airlangga, muhammad-ai@fkm.unair.ac.id

Corresponding Author: Chatarina Umbul Wahjuni, chatarina.uw@fkm.unair.ac.id, Departement of Epidemiology, Faculty of Public Health, Universitas Airlangga, Surabaya, East Java, 60115, Indonesia
\end{abstract}

\section{ARTICLE INFO}

Article History:

Received July, $8^{\text {th }}, 2019$

Revised form July, $17^{\text {th }}, 2019$

Accepted January, $21^{\text {st }}, 2020$

Published online January, $28^{\text {th }}, 2020$

\section{Keywords:}

tuberculosis;

spatial;

bali;

risk factors;

spatial error model

\section{Kata Kunci:}

tuberkulosis;

spasial;

bali;

faktor risiko lingkungan,

model spasial error

\begin{abstract}
Background: Indonesia is one of countries with a quite high incidence of tuberculosis. One of the regions which has issue of tuberculosis incidence is Bali Province with a case notification rate that tends to increase in the last three years so that it has an impact on increasing the risk of disease transmission. Purpose: This research aims to identify the risk factor based on the environment/spatial incidence of the tuberculosis in Bali Province. Methods: This research used ecological study design through secondary data obtained from the Health Office of Bali Province, Indonesian Statistics of Bali Province, and Environmental Office of Bali Province. The dependent variable was tuberculosis incidence, while the independent variable was the level of $\mathrm{PM}_{10}$, population density, poverty percentage, healthy house percentage, percentage of Clean and Healthy Lifestyle (PHBS), ratio of healthcare facilities with the community. Results: The statistical model was obtained in the form of Spatial Error Model (SEM) with model $\hat{y}_{\mathrm{i}}=1612,57+0,96 *$ level of $\mathrm{PM}_{10}+0,04 *$ population density $-2,56 *$ poverty $-0,58 *$ Healthy house $-3,099 *$ PHBS $-0,006 *$ health care facility, where $\mu_{\mathrm{i}}=0,90$ $\sum_{j=I, i \neq j}^{n} w_{i j} \varepsilon_{j}$. Conclusion: The risk factor spatially affected the tuberculosis incidence in Bali Province, which were the factors of level of $\mathrm{PM}_{10}$, population density, poverty percentage, healthy house percentage, percentage of PHBS, and ratio of healthcare facilities with the community.
\end{abstract}

C2020 Jurnal Berkala Epidemiologi. Published by Universitas Airlangga. This is an open access article under CC-BY-SA license (https://creativecommons.org/licenses/by-sa/4.0/)

How to Cite (APA): Saputra, F. F., Wahjuni, C.U., \& Isfandiari, M. A. (2020). Spatial modeling of environmental-based risk factors of tuberculosis in Bali Province: an ecological study. Jurnal Berkala Epidemiologi, 8(1), 26-34. https:/dx.doi.org/10.20473/ jbe.v8i12020.26-34

\begin{abstract}
ABSTRAK
Latar Belakang: Indonesia merupakan salah satu negara dengan angka insidens penyakit tuberkulosis yang cukup tinggi. Salah satu wilayah yang memiliki masalah terkait angka kejadian kasus tuberkulosis adalah Provinsi Bali dengan case notification rate yang cenderung meningkat dalam 3 tahun terakhir sehingga berdampak pada meningkatnya risiko penularan penyakit. Tujuan: Penelitian ini
\end{abstract}


bertujuan untuk mengidentifikasi faktor risiko berbasis lingkungan pada kejadian tuberkulosis serta menyusun pemodelan berbasis spasial faktor risiko berbasis lingkungan/keruangan kejadian tuberkulosis di Provinsi Bali. Metode.: Penelitian ini menggunakan desain studi ekologi dengan data sekunder dari Dinas Kesehatan Provinsi Bali, Badan Pusat Statistik Provinsi Bali dan Dinas Lingkungan Hidup Provinsi Bali. Variabel dependen adalah insidens tuberkulosis, sedangkan variabel independen adalah kadar $P M_{10}$, kepadatan penduduk, persentase kemiskinan, persentase rumah sehat, persentase Perilaku Hidup Bersih dan Sehat (PHBS), rasio fasilitas kesehatan dengan penduduk. Hasil: Setelah dilakukan uji statistik didapatkan model terbaik dengan bentuk spatial error model (SEM) dengan model $\hat{y}_{i}=1612,57+0,96 *$ Kadar PM $10+0,04 *$ Kepadatan penduduk- 2,56* Kemiskinan - 0,58* Rumah Sehat - 3,09 $*$ PHBS-0,006 * Fasilitas Kesehatan dengan $\mu_{i}=0,90$ $\sum_{j=I_{i} i \neq j}^{n} w_{i j} \varepsilon_{j}$. Kesimpulan: Faktor risiko yang secara spasial berpengaruh terhadap kejadian tuberkulosis di Provinsi Bali yaitu faktor Kadar PM10, kepadatan penduduk, persentase kemiskinan, persentase rumah sehat, persentase PHBS, rasio fasilitas kesehatan dengan penduduk.

(C2020 Jurnal Berkala Epidemiologi. Penerbit Universitas Airlangga. Jurnal ini dapat diakses secara terbuka dan memiliki lisensi CC-BY-SA (https://creativecommons.org/licenses/by-sa/4.0/)

\section{INTRODUCTION}

Tuberculosis is one of the deadliest infectious diseases in the world. There are 9.60 million incidences per year that is estimated to have killed around 1.50 million people in 2014 (Raviglione \& Sulis, 2016). In 2014, approximately 1.70 billion people were estimated to be infected by tuberculosis bacteria (Houben \& Dodd, 2016).

There are several risk factors of tuberculosis, such as age, sex, smoking, alcohol use, living condition, and HIV co-infection (Workneh, Bjune, \& Yimer, 2017). In addition to being caused by individual factors, the risk factors of tuberculosis can also be caused by ecological, geography, climate, and socioeconomic factors (Sun et al., 2015). Air pollution and migration are also risk factors of tuberculosis (Kaushik, Lowbridge, Scandurra, \& Dobler, 2018; Rajael et al., 2018).

Indonesia is a country with a high incidence of tuberculosis. In 2013, the incidence of tuberculosis in Indonesia reached 183 cases per 100,000 population and increased dramatically to 391 cases per 100,000 population in 2016 (Ministry of Health RI, 2017).

One of the areas that have problems related to the incidence of tuberculosis is Bali Province. The Case Notification Rate (CNR) of tuberculosis sufferers in the province in the last 3 years tended to increase. In 2015, the case notification rate was
69.30 cases per 100,000 population. This number increased in 2016 to 74.56 cases per 100,000 population, and in 2017 the case notification rate increased again to 82.41. Tuberculosis is an infectious disease that the bacteria are spread through the air from one person to another. The higher CNR rate, the higher the disease transmission (Bali Provincial Health Office, 2018)

Bali is one of the popular destinations for both domestic and foreign tourists, therefore it must provide safety and comfort for its visitors, especially from the threat of disease, and one of which is tuberculosis. Tuberculosis risk factors do not only come from individual but also from other factors: ecological and geographic factors (spatial factors). One of the methods that can be used to identify the risk factors is through spatial analysis. The results of the spatial analysis can be used by related parties to take effective preventive measures according to the risk factors in a region. The aim of this study was to identify the risk factors based on the environmental/spatial incidence of tuberculosis and compile spatialbased modeling of the risk factors of tuberculosis in Bali Province.

\section{METHODS}

This research is an ecological study with a spatial approach based on the area carried out in 
Bali Province. This study used secondary data published by Bali Provincial Health Office, Bali Provincial Environment Agency, and Bali Provincial Central Statistics Agency (BPS). The population of this research was all regencies/municipalities in the administrative area of Bali Province.

The dependent variable of this research are the incidence of tuberculosis in each regency/municipality in Bali Province, which was collected from the profile of the Bali Provincial Health Office. The independent variable of this research are the percentage of poverty in each regency/municipality in Bali Province, which was collected from the publication of report by the Bali Provincial Central Statistics Agency. The ratio of health facilities to the population mentioned in this research is the ratio of health facilities (public health center, public health sub-center, medical practice, and drugstore) to residents in each regency/municipality in Bali Province compiled from the report of the Provincial Central Statistics Agency of Bali. The population density meant in this study is the ratio between the population and area in each regency/municipality collected from the report of the Central Statistics Agency of Bali Province. The percentage of healthy homes mentioned is the percentage of healthy homes from each regency/municipality collected from the health profile of Bali. Moreover, the percentage of Clean and Healthy Lifestyle (PHBS) is the percentage of clean and healthy lifestyle of households in each regency/municipality in Bali that is known from the health profile of Bali. Furthermore, the Particulate Matter $\left(\mathrm{PM}_{10}\right)$ is the level of $\mathrm{PM}_{10}$ in each regency/municipality in Bali Province collected from Bali Provincial Environment Service Report.

The data obtained were then analyzed spatially to illustrate the distribution of the incidence and risk factors of tuberculosis in Bali. The relationship between the independent variable and dependent variable was analyzed using spatial regression with a $90 \%$ confidence level. The data analysis was performed using the Quantum GIS and GeoDa applications on computer.

\section{RESULTS}

The ratio of health facilities to the residents in Bali Province mostly had a range of 1 health facility compared to 4001-8001 residents. This condition was found in 3 regencies, which are Gianyar, Buleleng, and Jembrana. By this ratio, every 1 health facility had to bear 4001-8001 residents. The highest ratio of health facilities was in Denpasar City which was the capital of Bali Province with a ratio of 1 health facility compared to 16001-20000 population. The case of tuberculosis and the ratio of health facilities to the population in Bali Province tended to be positive meaning that the region that had a low ratio of health facilities tended to have low cases of the disease, as happened in Buleleng Regency. This also applied vice versa, if the ratio of health facilities is high, then the incidence of existing tuberculosis case will also be high, as happened in Denpasar City (Figure 1).

The population density in Bali Province tended to be low. However, the population density tended to differ greatly in the suburbs and in the provincial capital city of Denpasar which the population density is $6000-7500$ inhabitants $/ \mathrm{km} 2$. The population density in Bali tended to be positive with the incidence of tuberculosis in the province. The regencies/municipalities that have high population density tend to have high incidence of tuberculosis (Denpasar City), and vice versa (Bangli Regency). (Figure 2).

The households applying PHBS in Bali Province tended to be evenly distributed in regencies/municipalities. There were four regencies/municipalities having the percentage of PHBS of $60-80 \%$ and four other regencies/municipalities having the percentage of PHBS of $80-100 \%$. The relationship between the percentages of PHBS with the incidence of tuberculosis in Bali tended to fluctuate, where the region that had a high percentage of PHBS also had a high incidence of tuberculosis (such as Denpasar City). There was also an area that had a high percentage yet had a low incidence of tuberculosis (Bangli Regency). See Figure 3.

There was only one regency which had a fairly low percentage of healthy homes that was Bangli District, with a percentage of healthy homes of only $40-60 \%$, while other regencies in Bali Province had reached $80-100 \%$. The relationship between the percentage of healthy homes in each regency/municipality in Bali Province tended to be positive, where almost all regencies/municipalities that had high percentage of healthy homes tended to have medium to high incidence of tuberculosis. In addition, only Bangli District that had medium percentage of healthy homes, but had a low case rate (Figure 4).

The Particulate Matter $10\left(\mathrm{PM}_{10}\right)$ level in Bali Province showed high enough number and all regencies/municipalities that had PM10 level above 200. Even, there were three regions with 
$\mathrm{PM}_{10}$ level of 300-400 (Badung, Klungkung and Jembrana Regencies). The $\mathrm{PM}_{10}$ level and the incidence of tuberculosis in Bali Province were directly proportional to the incidence of tuberculosis in almost all regencies/municipalities

HEALTH CARE RATIO

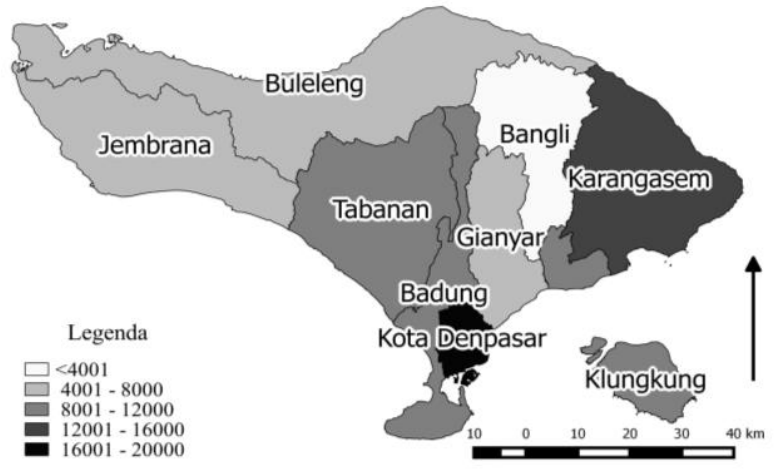

in the province. The higher the $\mathrm{PM}_{10}$ level in the air, the higher the tuberculosis incidence rate. However, Bangli District was the only regency that had high $\mathrm{PM}_{10}$ level, but had low incidence rate of the cases (Figure 5).

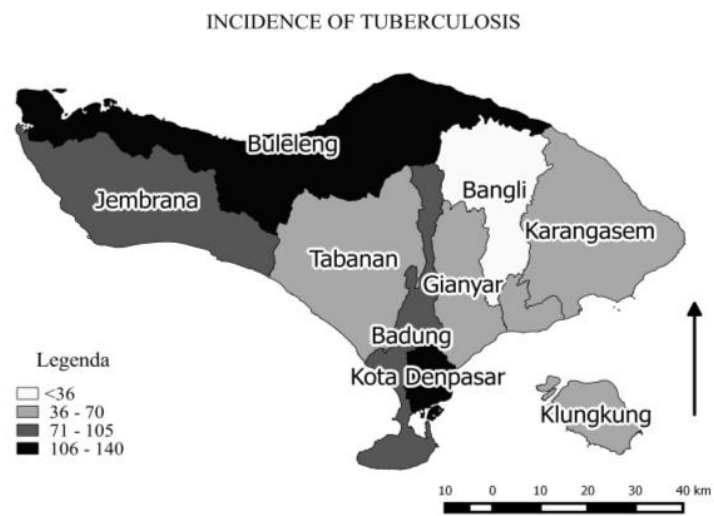

Source : BPS Bali Province, (2018); Dinkesprov Bali (2018)

Figure 1. Ratio of Health Facilities and Incidence of Tuberculosis in the District/City of Bali Province in 2017

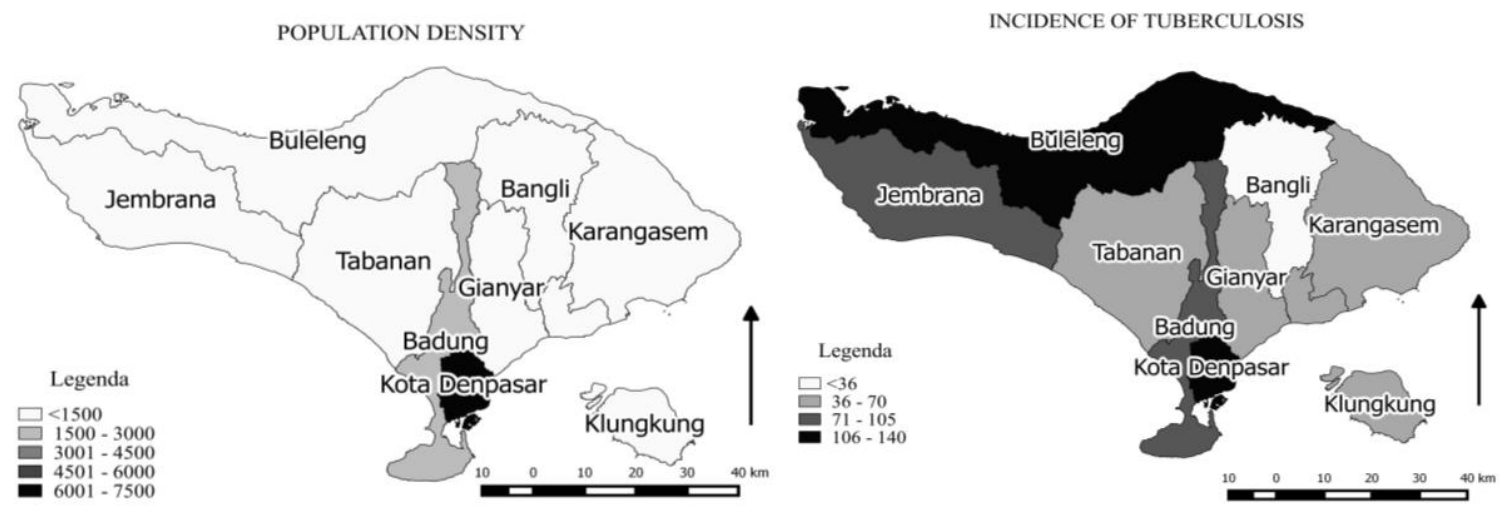

Source : BPS Bali Province, (2018); Dinkesprov Bali (2018)

Figure 2. Population Density and Incidence of Tuberculosis in the District/City of Bali Province in 2017

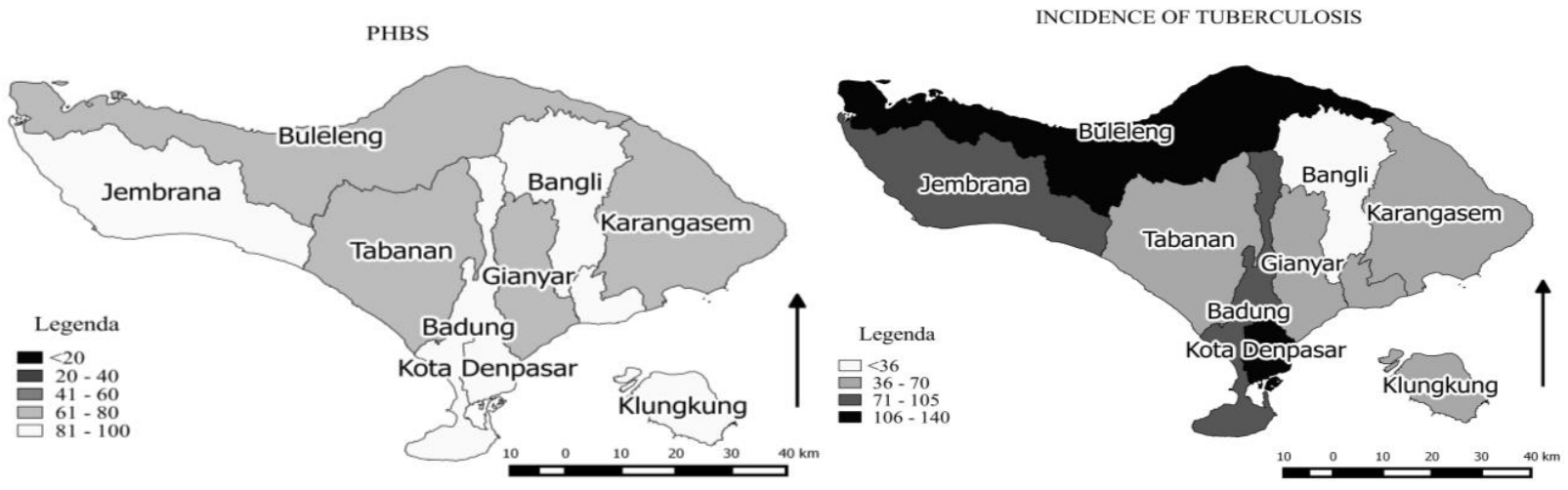

Source : BPS Bali Province, (2018); Dinkesprov Bali (2018)

Figure 3. Clean and Healthy Lifestyle (PHBS) and Incidence of Tuberculosis in the District/City of Bali Province in 2017 


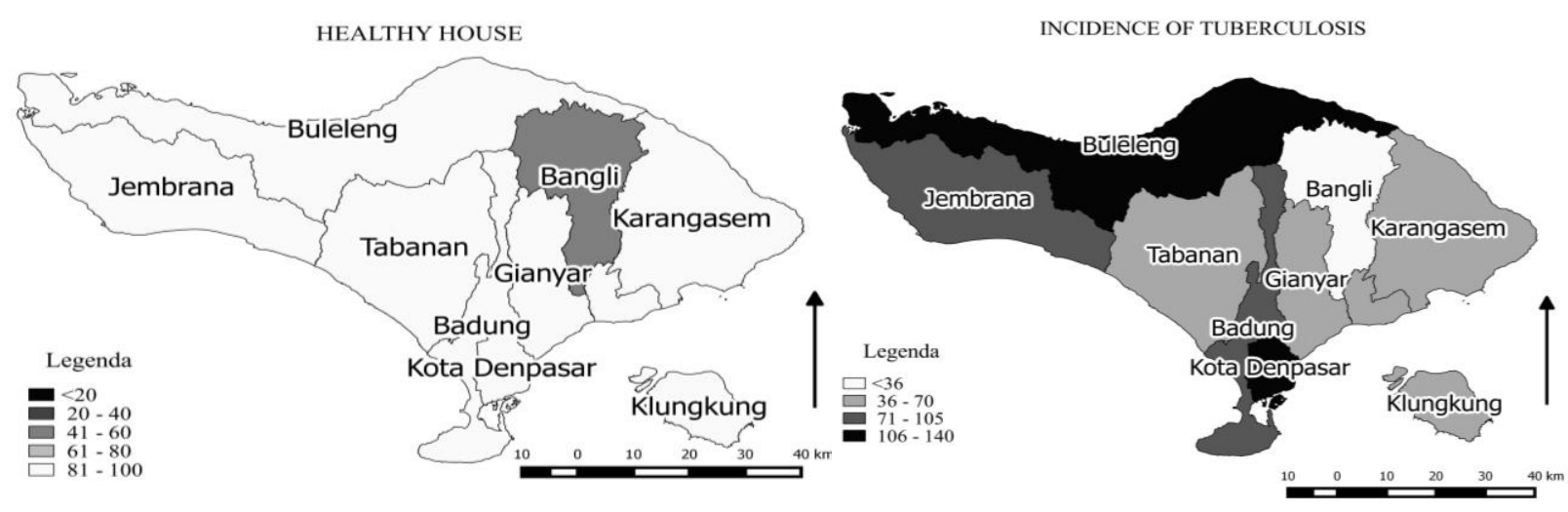

Source : BPS Bali Province, (2018); Dinkesprov Bali (2018)

Figure 4. Healthy House and Incidence of Tuberculosis in the District/City of Bali Province in 2017

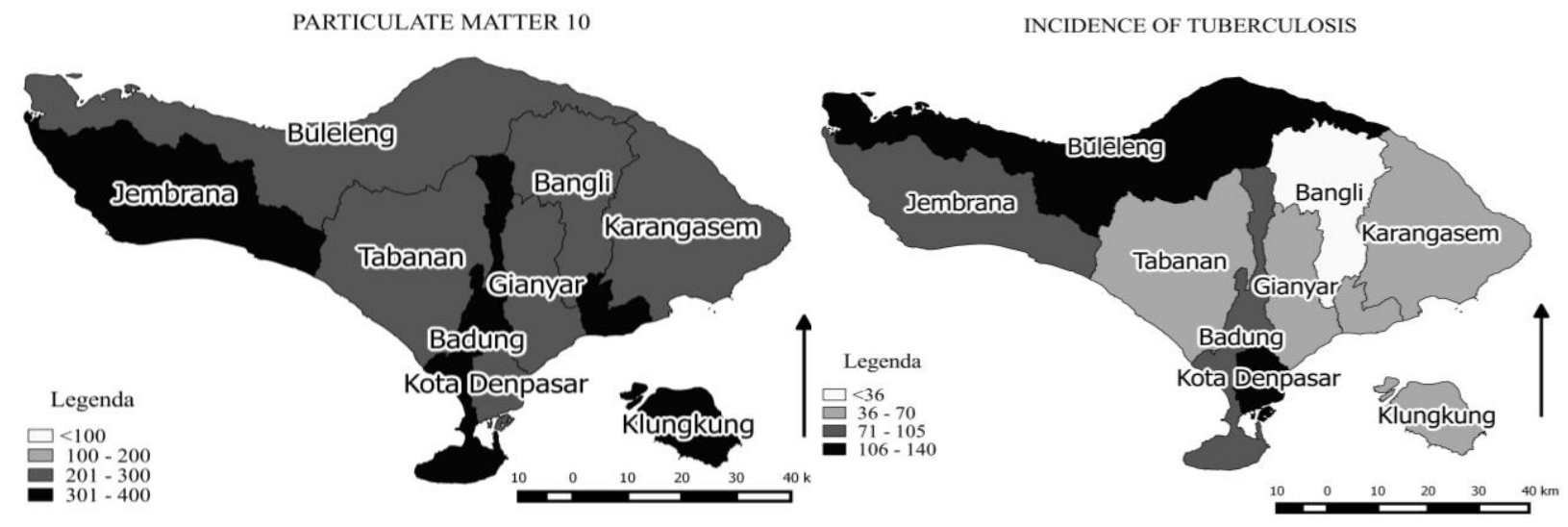

Source : BPS Bali Province, (2018); Dinkesprov Bali (2018)

Figure 5. Particulate Matter 10 and Incidence of Tuberculosis in the District/City of Bali Province in 2017

There were two assumptions that must be fulfilled before conducting the spatial regression test, which were spatial autocorrelation (Moran's I test) in the regions and spatial heterogeneity (Breusch-Pagan test). The result of the Moran's' I test carried out was $0.02(\mathrm{p}<\mathrm{a})$, between adjacent locations that tended to have similar values and groups. The Breusch-Pagan test result showed $\mathrm{p}=0.099>\mathrm{a}=0.10$, so it could be concluded that there was a spatial diversity. The determination of the best spatial model needed to be done using the Lagrange Multiplier (LM) test. The result indicated the Lagrange multiplier (lag) was not significant $(0.78>0.1)$, while the Lagrange multiplier (error) test was carried out significantly $(0.00>0.1)$. The LM test result showed that the best spatial model that could be done is Spatial Error Model (SEM).

Based on the result of the Spatial Error Model (SEM) analysis, it was known that all variables were spatially related to the incidence of tuberculosis in Bali Province (Table 1). The model formed was as follows:

$\hat{y}_{\mathrm{i}}=1612,57+0,96 * \mathrm{PM}_{10}$ Level $+0,04 *$ Population Density - 2,56* Poverty - 0,58* Healthy House $-3,09 *$ Clean and Healthy Lifestyle (PHBS) $-0,006 *$ Health Center, where $\mu_{\mathrm{i}}=0,90 \sum_{j=I_{i} i \neq j}^{n} w_{i j} \varepsilon_{j}$.

The spatial model above can be explained that if the $\mathrm{PM}_{10}$ level factor rises by 10 digits and other factors are constant, the number of tuberculosis cases increase by 9.60 . If the population density factor increases by 100 points and other factors are constant, the number of tuberculosis cases increase by 4 . If the poverty factor decreases by 10 points and other factors are constant, the number of tuberculosis cases would reduce by 3 . If the healthy house factor decreases by 10 points and other factors are constant, the number of tuberculosis cases increase by 6 . If the PHBS factor decreases by 1 number and the other factors 
are constant, the number of tuberculosis disease increase by 3 . If the ratio of health facilities to population decreases by 1000 points and other factors are constant, the number of tuberculosis cases increase by 6 .

According to the analysis that has been done, $\mathrm{R} 2$ is $95.93 \%$. This shows that the model resulted can explain the incidence of tuberculosis in Bali by $95.93 \%$ and the rest is influenced by other variables outside the model (Table 1).

\section{DISCUSSION}

This study showed that $\mathrm{PM}_{10}$ level is one of the risk factors associated with the incidence of tuberculosis in Bali Province. Air pollution causes the decrease in the production of tumor necrosis factor (TNF) $-\alpha$ and interferon-gamma (IFN- $\gamma$ ) which have a role in inhibiting the growth of Mycobacterium bacteria (Smith et al., 2016). If the pollution by $\mathrm{PM}_{10}$ level inhaled, it will sediment in the lungs and cause infection, thus indirectly affects the development of tuberculosis (Rajael et al., 2018). The result of this study is in line with the research conducted by Zhu et al (2018) which stated that a house with a high $\mathrm{PM}_{10}$ level of air pollution could increase the risk of developing tuberculosis by 1.25 times greater than a house that did not have air pollution/ $\mathrm{PM}_{10}$ level is normal. This study is also in line with the research of Liu et al (2018) which stated that polluted air condition increased the risk by 1.58 times greater for people experiencing tuberculosis compared with those were not.

The population density is one of the risk factors associated with the incidence of tuberculosis. Tuberculosis is a disease that is transmitted from one person to another through the air. High population density increases the opportunities for interaction or contact between people that increase the transmission of disease
(Siwiendrayanti, Sukendra, \& Arofah, 2018). The result of this study is in line with the research conducted in Lampung Province which stated that the population density of an area, spatially, was one of the risk factors of tuberculosis, when the population density increased by 1000 population per $\mathrm{km} 2$, the number of cases would increase by 11.78 cases (Rosari, Bakri, Santoso, \& Wardani, 2017). The result of this study was also in line with the research conducted in Jember which showed that areas with high tuberculosis cases were caused by high population density and inadequate health facility ratios (Hikma, Amareta, \& Maharani, 2016).

The poverty rate in Bali Province is also one of the risk factors associated with the incidence of tuberculosis. The poverty experienced by the community will greatly affect their quality of life. This is because poverty will affect lifestyle, nutritional intake, and living condition (population density and environment condition (Harling \& Castro, 2014). The result of this study is also in line with research conducted by Siroka et al (2016) which stated that there was a relationship between low socioeconomic condition in a country with tuberculosis incidence such as those occurring in Mongolia, Myanmar, Tanzania and Vietnam. The result of this study also have similar result to the study conducted by Syukur \& Pakaya (2015) which found out that the economic level of a person at underprivileged level had a significant relationship with the incidence of tuberculosis. The research conducted by Ortblad, Salomon, Bärnighausen, \& Atun (2019) found that from the result of the analysis conducted on the determinants of tuberculosis incidence, it was known that there was a significant relationship between poverty, sanitation, access to clean water and electricity, and nutritional intake with the incidence of tuberculosis.

\section{Table 1}

Spatial error test results of a risk factor model for the incidence of tuberculosis in Bali Province

\begin{tabular}{lrrrr}
\hline Variable & \multicolumn{2}{c}{ SE } & \multicolumn{2}{c}{$p$} \\
\hline Constant & 1612.57 & 184.03 & 8.76 & 0,00 \\
Kadar PM PM $_{10}$ & 0.96 & 0.09 & 9.90 & $0,00^{*}$ \\
Kemiskinan & -2.56 & 1.44 & -1.77 & $0,07^{*}$ \\
Perilaku Hidup Bersih dan Sehat Keluarga & -3.09 & 0.51 & -6.00 & $0,00^{*}$ \\
Rumah Sehat & -0.58 & 0.21 & -2.77 & $0,00^{*}$ \\
Fasilitas Kesehatan & -0.00 & 0.00 & -6.66 & $0,00^{*}$ \\
Kepadatan Penduduk & 0.04 & 0.00 & 12.09 & $0,00^{*}$ \\
Lamda & 0.90 & 0.06 & 13.52 & 0,00 \\
\hline
\end{tabular}

*significance $\mathrm{p}<\mathrm{a}(0.01), R^{2}=0.959379$ 
Healthy home is one of the important variables that can influence the incidence of tuberculosis. Healthy homes, with low occupancy density, adequate lighting, adequate ventilation size, waterproof floor type, good air humidity and temperature can prevent tuberculosis. The result of this study is in line with the research by Hakim (2018) which showed that there was a significant relationship $(\mathrm{p}<\alpha)$ between healthy homes and incidence of tuberculosis in East Java. This study is also in accordance with the research conducted by Lestari (2019) in Pabean Cantikan Sub-district of Surabaya which found out that poor home environment influenced tuberculosis with an odd ratio of 9 times compared to good environment.

Clean and healthy life behavior or commonly abbreviated as PHBS is one of the variables associated with the incidence of tuberculosis. There are several aspects of PBHS that can be related to tuberculosis incidence such as nonsmoking behavior at home and physical activity every day. The research conducted by Nisa' \& Budiantara (2016) stated that PHBS was a risk factor for tuberculosis in East Java. The result of modeling that has been done stated that when PHBS rate rises by 1 percent, it can reduce tuberculosis incidence by 12 cases.

The main function of health facilities is to carry out optimal preventive and efforts to the community so that the community can prevent the onset of an illness. The good ratio between the number of health facilities and population density will help the population to get maximum services, so they can avoid a disease, such as tuberculosis (Wikurendra, 2018). The result of this study is in line with the research conducted by Chairani \& Mariana (2017) which suggested that the access to health facilities was a risk factor in the incidence of tuberculosis in an area, where regions having poor health access had the opportunity to experience tuberculosis cases as much as 3.80 times greater than regions having good health access.

\section{Research Limitations}

The population studied in this research is nine regencies/municipalities with only seven variables that can be analyzed. This is because the application used to conduct spatial regression analysis is GeoDa which cannot perform variable analysis exceeds the number of observation units, thus the number of variables that can be analyzed is limited.

\section{CONCLUSION}

The risk factors that spatially influence the incidence of tuberculosis in Bali Province are $\mathrm{PM}_{10}$ level, population density, poverty rate, healthy homes percentage, PHBS percentage, and ratio of health facilities to population. The application of appropriate intervention to overcome the existing tuberculosis problem can be done by various parties, not only the health department but also all across sectors. Tuberculosis is not only caused by the risk factors originating from the health sector but also from other factors such as poverty rate and population density. Good cooperation between sectors can reduce the incidence of tuberculosis in Bali, thus it will affect the comfort of tourists visiting Bali since Bali is as one of the world-class tourist destinations.

\section{CONFLICT OF INTEREST}

The authors declare that no conflict of interest in this study.

\section{ACKNOWLEDGMENT}

The researcher would like to express gratitude to Bali Provincial Health Office, Bali Provincial Statistics Agency, and Bali Provincial Environment Office for the help to conduct this research.

\section{REFERENCES}

Bali Provincial Health Office. (2018). Bali province health profile 2017. Denpasar: Bali Provincial Health Office.

BPS Provinsi Bali. (2018). Provinsi Bali dalam angka. Badan Pusat Statistik Provinsi Bali. Denpasar.

Chairani, M., \& Mariana, D. (2017). Faktor risiko kejadian tuberkulosis paru di wilayah kerja Puskesmas Binanga Kabupaten Mamuju. Jurnal Penelitian Kesehatan Suara Forikes, 8(3), 140-145.

Hakim, R. N. (2018). Pengaruh jumlah kasus HIV/AIDS dan cakupan rumah sehat terhadap jumlah kasus tuberkulosis di Provinsi Jawa Timur. Jurnal Biometrika Dan Kependudukan, 7(2), 141-148.

Harling, G., \& Castro, M. C. (2014). A spatial analysis of social and economic determinants of tuberculosis in Brazil. Health Place, 25, 56-67. 
Hikma, F., Amareta, D. I., \& Maharani, H. (2016). Pemetaan persebaran penyakit tuberkulosis di Kabupaten Jember tahun 2013-2015. Jurnal Manajemen Informasi Kesehatan Indonesia, $4(1), 27-39$.

Houben, R. M. G. J., \& Dodd, P. J. (2016). The global burden of latent tuberculosis infection: a re-estimation using mathematical modelling. PLoS Medicine, 13(10), 1-13. https://doi.org/10.1371/journal.pmed.100215 2

Kaushik, N., Lowbridge, C., Scandurra, G., \& Dobler, C. C. (2018). Post-migration followup programme for migrants at increased risk of developing tuberculosis: a cohort study. ERJ Open Research, 4(3), 1-8. https://doi.org/10.1183/23120541.000082018

Lestari, J. W. (2019). Pengaruh tingkat pengetahuan penyakit $\mathrm{TBC}$, rutinitas berobat dan kondisi lingkungan rumah terhadap kejadian TBC di Kecamatan Pabean Cantikan Kota Surabaya. Swara Bhumi EJournal Pendidikan Geografi FIS Unesa, I(1), 1-10.

Liu, Y., Cui, L. L., Hou, L. J., Yu, C. B., Tao, N. N., Liu, J. Y., ... Li, H. C. (2018). Ambient air pollution exposures and newly diagnosed pulmonary tuberculosis in Jinan, China: a time series study. Scientific Reports, 8(1), 111. https://doi.org/10.1038/s41598-01835411-6

Ministry of Health RI. (2017). Indonesia health profile 2016. Jakarta: Ministry of Health RI.

Nisa', F. F., \& Budiantara, I. N. (2016). Pemodelan faktor - faktor yang mempengaruhi regresi nonparametrik spline di Jawa Tengah. Jurnal Sains dan Seni ITS, 5(2), 271-273.

Ortblad, K. F., Salomon, J. A., Bärnighausen, T., \& Atun, R. (2019). Stopping tuberculosis: a biosocial model for sustainable development. HHS Public Access: Lancet, 386(10010), 2354-2362. https://doi.org/10.1016/S01406736(15)00324-4.Stopping

Rajael, E., Hadadi, M., Madadi, M., Aghajani, J., Ahmad, M. M., Farnia, P., ... Velayati, A. A. (2018). Outdoor air pollution affects tuberculosis development based on geographical information system modelling. Biomedical and Biotechnology Research Journal, 2, 39-45. https://doi.org/10.4103/bbrj.bbrj

Raviglione, M., \& Sulis, G. (2016). Tuberculosis 2015: burden, challenges and strategy for control and elimination. Infectious Disease Reports, 8(6570), 33-37. https://doi.org/10.4081/idr.2016.6570

Rosari, R., Bakri, S., Santoso, T., \& Wardani, D. W. S. R. (2017). Pengaruh perubahan penggunaan lahan terhadap insiden penyakit tuberkulosis paru: studi di Provinsi Lampung. Jurnal Sylva Lestari, 5(1), 71-80.

Siroka, A., Law, I., Macinko, J., Floyd, K., Banda, R. P., Hoa, N. ., ... Ponce, N. A. (2016). The effect of household poverty on tuberculosis. HHS Public Access: International Journal Tuberculosis Lung Disease, 20(12), 16031608.

Siwiendrayanti, A., Sukendra, D. M., \& Arofah, D. (2018). Analisis spasial dan temporal persebaran kasus baru TB paru BTA (+) di Kabupaten Batang. Jurnal Kesehatan Lingkungan Indonesia, 17(2), 95-103. https://doi.org/10.14710/jkli.17.2.95-103

Smith, G. S., Van Den Eeden, S. K., Garcia, C., Shan, J., Baxter, R., Herring, A. H., ... Gammon, M. D. (2016). Air pollution and pulmonary tuberculosis: a nested casecontrol study among members of a Northern California health plan. Environmental Health Perspectives, 124(6), 761-768. https://doi.org/10.1289/ehp.1408166

Sun, W., Gong, J., Zhou, J., Zhao, Y., Tan, J., Ibrahim, A. N., \& Zhou, Y. (2015). A spatial, social and environmental study of tuberculosis in China using statistical and GIS technology. International Journal of Environmental Research and Public Health, 12(2), 1425-1448. https://doi.org/10.3390/ijerph120201425

Syukur, S. B., \& Pakaya, A. W. (2015). Faktorfaktor yang berhubungan dengan kejadian TBC paru di wilayah kerja Puskesmas Bolangitan. Jurnal Zaitun, 8(2), 55-62.

Wikurendra, E. A. (2018). Pemetaan dan analisis spasial faktor risiko kasus tuberkulosis paru BTA positif di Kota Surabaya. Thesis. Faculty of Public Health. Universitas Airlangga.

Workneh, M. H., Bjune, G. A., \& Yimer, S. A. (2017). Prevalence and associated factors of tuberculosis and diabetes mellitus comorbidity: a systematic review. PLOS ONE, 12(4), 1-25. https://doi.org/10.1371/journal.pone.0175925

Zhu, S., Xia, L., Wu, J., Chen, S., Chen, F., Zeng, F., ... Zhang, J. (2018). Ambient air pollutants are associated with newly diagnosed tuberculosis: a time-series study in 
34 of 34 Firman Firdauz Saputra, et al / Jurnal Berkala Epidemiologi, 8 (1) 2020, 26 - 34

Chengdu, China. Science of the Total Environment, 3(17), 47-55.

https://doi.org/10.1016/j.scitotenv.2018.03.0

17 